
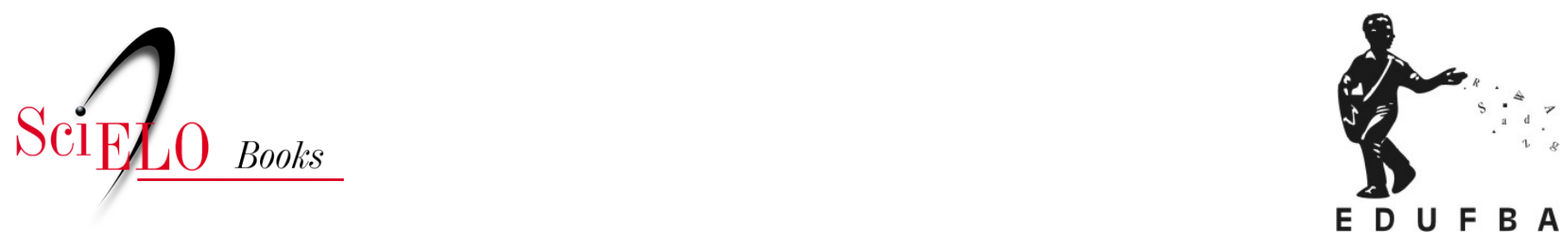

\title{
Reflexões \\ Educação e produtivismo: pacto perigoso
}

\author{
Nelson De Luca Pretto
}

PRETTO, N.D.L. Educação e produtivismo: pacto perigoso. In: Educações, culturas e hackers: escritos e reflexões [online]. Salvador: EDUFBA, 2017, pp. 187-188. ISBN: 978-85-232-2019-8.

https://doi.org/10.7476/9788523220198.0052.

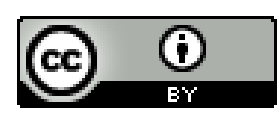

All the contents of this work, except where otherwise noted, is licensed under a Creative Commons Attribution $\underline{4.0 \text { International license. }}$

Todo o conteúdo deste trabalho, exceto quando houver ressalva, é publicado sob a licença Creative Commons Atribição 4.0. 
De fato, com essa realidade, fica muito difícil o trabalho desses profissionais que precisam, antes de tudo, altivez profissional. Somos responsáveis pela formação dos jovens que amanhã serão o futuro do país e não é possível que ainda continuemos a ser tão pouco valorizados pela sociedade.

Publicado no jornal Correio*, Salvador, em 4 de junho de 2015.

\section{Educação e produtivismo: pacto perigoso}

Educação é sempre tema presente nas campanhas eleitorais. Não foi diferente nas últimas eleições no Brasil e o tema continua nas pautas dos governos.

No plano nacional, viramos uma pátria educadora, com direito a filósofo como Ministro da Educação (Renato Janine Ribeiro, professor da USP). No plano estadual, o governador Rui Costa (PT-Bahia) anuncia, com o merecido louvor, desde o primeiro dia de mandato, que passará em pelo menos uma escola pública em cada município que visitar, o que significará sua presença em pelo menos 417 escolas públicas nos seus quatro anos de mandato.

A educação está em pauta, é verdade, porém, infelizmente, com modelos que se mostraram insatisfatórios para o enfrentamento dos desafios históricos e, claro, anacrônicos para os desafios de hoje, muito mais profundos e complexos.

A ênfase, desde há muito, tem sido na gestão. Não que esse foco seja irrelevante, mas é óbvio que essa abordagem não dá conta do tamanho do desafio. Parece-nos que insiste o governador em ouvir somente quem pensa a educação a partir dessa perspectiva e, quando decide avançar, traz 
para a cena propostas dissonantes do que pode e deve ser um sistema educacional que queira efetivamente construir uma pátria educadora. A sua última declaração, no jornal $A$ Tarde - "Premiação estimulará qualidade do ensino nas escolas públicas” (31.03.2015) -, foi anunciando que adotará o conhecido sistema de pagamento por performance, ou seja, professores, escolas e municípios que "garantirem excelência”, receberão bonificações financeiras. Lamentável. A Inglaterra, na década de 1990, tentou implantar sistema igual e sofreu dura reação da academia, sindicatos e população. Acompanhei de perto aquela reação, pois lá estava em um pós-doutoramento. Essa também é a proposta que agrada ao PSDB do governador José Serra, que tentou implantar o mesmo sistema quando administrava São Paulo e que também sofreu severas criticas da academia e dos sindicatos de docentes. Nos Estados Unidos, berço de propostas baseadas nesses princípios produtivistas e de mercado, elas também foram alvo de críticas. Sugiro ao governador e ao secretário de educação, a leitura do livro da ex-secretária de educação dos governos Bush e Clinton, Diane Ravitch, que comandou a implantação de políticas centradas nessas bases e hoje faz duras críticas ao sistema, expondo-as em um livro cujo título já diz tudo: Vida e Morte do Grande Sistema Escolar Americano - como os testes padronizados e o modelo de mercado ameaçam a educação.

Educação não pode ser compreendida a partir da lógica produtivista do mercado. Educação é cooperação, é trabalho coletivo e colaborativo, de compartilhamento de conhecimentos e saberes, e não admite a implantação de ambiência de competitividade e de estímulo a performances individuais, o que a exporia a perder em seus propósitos fundamentais.

As escolhas estão postas, governador. Resta fazer opções coerentes com o modelo de sociedade que queremos construir. 